\title{
A LIFE WITHOUT HEALTH IS A USELESS LIFE:' COMPARING FOLK AND BIOMEDICAL INTERPRETATIONS OF DISEASE IN MACEDONIA
}

Key words: body, health, disease, illness, folk culture, Macedonia, epidemics, European history, biomedicine, psychosomatic illness

\section{Normal versus Pathological}

The changes our bodies experience throughout our lifecycles can threaten our feeling of who we are and shake the balance of our sense of self. The existence of a framework for interpreting these changes therefore plays a key role in maintaining the integrity of not only individuals, but also the social structure that they are part of. This would otherwise collapse if there were not a conceptual binding tissue that harmonized the principles of dynamism and randomness with those of continuity and certainty, as a basis of stability.

The conceptual framework, the instrument for interpreting the changes experienced by our bodies, is health (or disease). ${ }^{2}$ Which signs are treated

1 A Macedonian folk proverb.

2 Following Kleinman's dichotomy $(1982,72)$, wherever applicable this article tries to differentiate between disease (referring to malfunctioning of biological and/or psychological processes) and illness (referring to psychosocial experience and the meaning of perceived disease). However, the primary and secondary ethnographic material used in this research did not show that the same distinction is made in the frameworks of folk interpretation of health-related phenomena. This article shows that these two concepts (one emphasizing the biological aspect, and the other the social aspect of the disease) form an integral whole in Macedonian folk culture. Moreover, the social environment can be sometimes considered a source of the (biological) malfunctioning of the organism. At such points in the text I there- 
as symptoms of a certain disease, whether these changes should be considered normal or pathological, what the list of potential diagnoses is like, what the gradation of the seriousness of the diseases is, and, consequently, how the social treatment and status of an ill person is defined - all of this depends on the criteria of a certain culture for how the healthy body should look and function; that is, what makes a healthy person. This ideal model is a criterion for defining a certain change in the organism in the sense of its divergence from the optimal equilibrium (homeostasis), as well as a criterion for estimating the level of this divergence that influences its normal function. Thus, the concept of health defines, but also excludes, the concept of disease (i.e., illness) and vice-versa. In fact, it is quite simple: a healthy person is one that is not ill, and an ill person is one that is not healthy.

Folk medicine, which is defined as a model of recognizing and treating diseases that have historically appeared and which was developed in past rural communities, identifies a certain condition as pathological, diagnosing it and treating it based on a combination of traditional knowledge of anatomy (structure), physiology (function), and pathology (deviation of structure and function) of the human body, as well as knowledge of methods for curing it. Here folk medicine is considered only one of the branches of the great tree of (in the words of Geertz) "local" or "intimate" knowledge (2000), produced by and referring to the everyday life of village communities in a certain geographical and historical setting - in this case, Macedonian villagers at the beginning of the twentieth century. As the remainder of this article shows, this field of knowledge is closely interconnected with all other aspects of these people's culture, which is therefore termed "folk." The ultimate aim of both folk medicine and contemporary biomedicine is the same: based upon external signs and symptoms, both try to determine which of the known diseases is involved and to offer appropriate treatment. This article analyzes the potential overlap between these two systems of knowledge about the human body, the ways they function, the reasons one becomes ill and how one is cured, and the possible implications of both models (especially of the folk model) on the contemporary perceptions of these phenomena. At the same time, this article focuses on the social status

fore favor the term illness. 
and treatment of the person that is ill, an aspect that goes beyond medicine and extends into the wider social context.

Both folk and contemporary medicine (i.e., the western biomedical model for interpreting disease) agree that disease is a divergence from the normal condition of the body that could result in nuisance, pain, general dysfunction, or death. However, the primary difference between these two models lies in the agent that defines what is and what is not normal - the one that possesses socially verified knowledge about the interpretation of symptoms and identification of disease, the one that possesses the skill to cure - as well as in the actual place where these processes occur (i.e., the social sphere to which they belong). Specifically, in folk culture, interpretation of disease and its cure lies in the intimate sphere of the individual and it takes place in one's home or immediate surrounding. At home, women were the ones responsible for the health of the family: healthcare, especially when it came to children, was one of the many aspects of women's domestic work. This situation was identical in most of Europe until the seventeenth century: "Prior to the seventeenth century, orally transmitted and written systems of belief and practice often remained entirely within the private sphere, being passed down through generations of women, to be modified in turn by each woman's practical experience" (Billington, Hockey, and Strawbridge, 1998, 121).

When domestic remedies did not solve the problem, assistance was sought from local healers, mostly women, who possessed a great range of knowledge and skills regarding healing plants, preparation of balms, and especially magical curative procedures. In the sense of primary field data as well as analyzing this data, the most useful and richest material on the concept of illness in Macedonian folk culture comes from Józef Obrębski, a Polish anthropologist that worked in Macedonia in the 1930s, and his ethnographic materials from Poreče in central Macedonia. This material was chosen because it is relatively old. In comparison, recent research (including my own fieldwork on this topic, collected during summer 2006 in southwestern Macedonia in villages around Bitola and Ohrid from informants 45 to 75 years old), even when it involves older informants, still reflects the influence of the medicalized perception of the body and illness. Thus, results obtained using such recent material are not authentically "folk" in 
the previously established sense of this word. For example, although contemporaries know old names of diseases such as čuma 'plague' or crvenica 'measles', and are aware of the magical procedures for treating evil spells, they simultaneously use terms such as 'high blood pressure', 'thrombosis', or 'cancer' - concepts that are a result of their experience with official biomedicine and/or its lay form. This article examines the attitudes and models of interpretation of disease that still have not been touched by the hand of official medicine. Such attitudes were found in the work of Obrębski, and to a lesser extent in the works of other authors cited below.

\section{The Shift from Private to Public: Symbolic Barriers}

The chapters dedicated to folk medicine in Obrębski's Makedonski etnosociološki studii (Macedonian Ethno-Sociological Studies, 2001a) register the domination of women in this area, and even proclaim it as their monopoly. The fact that women played a major role in curing was also reported by Stevan Tanović in his study of the Gevgelija area (in southeast Macedonia), published in 1927:

The one that takes care of the ill person, if he is a man - it is his wife; if it is a child - the mother, if she is a woman - another woman. A man would seldom take care of his ill wife. When the illness starts to become serious, relatives are sought out, so that their wives come for a visit and bring punuda [some food or other necessities for the ill person]. (Tanović, 1927, 76)

When these two authors conducted their research (at the end of the 1920s), major cities in Macedonia already had doctors and hospitals - the first hospitals were opened in the first decade of the twentieth century for military needs. However, the terrain for establishing official medicine as the only relevant authority for health started to take shape even earlier: in 1869, the Ottoman Empire passed a law on the organization of medical service, forbidding nonprofessionals from practicing healing. This is also more or less the time when the first educated doctors from the local popu- 
lation appeared in Macedonia. These were sons (less often daughters) of well-off citizens, merchants, craftsmen, and economic migrants that had the opportunity to be educated abroad and formed the basis of the Macedonian intelligentsia of that time.

At roughly the same time (during the Balkan wars, and the first and second world wars), foreign medical doctors arrived in the large cities. They either had private practices or were part of military health units. By the end of the nineteenth and beginning of the twentieth century, the treatment of disease in Macedonia slowly started to be transferred from the private to the public sphere of official medicine and its institutions. Trust in the knowledge of folk medicine, based on life experience, built and transmitted through centuries, could not be replaced overnight with the same level of trust towards official medicine. Moreover, at least initially, official medicine was to a great extent based on folk wisdom, and it recognized its relevance. People sought medical help from urban professionals only in serious cases, after they had tried all other options available in their immediate surroundings.

This process started much earlier in the rest of Europe: the development of medicine in Europe in the sense of a professionalized space is registered after the seventeenth century, when individuals and their bodies for the first time became open to the public gaze of the authoritative representatives of the state (i.e., medical doctors). Ever since, medicine has been a specialized corpus of knowledge based on scientific advancements, and at the same time a high-status profession dominated by men. Foucault's book The Birth of the Clinic (2003) examines the modern, medicalized concept of the body and the world. Foucault asserts that the power inherent to medicine and the medical profession is constructed through knowledge, which one obtains not through books, but through medical practice, which on the other hand consists of observing patients' bodies, and even their minds. Introducing the term "medical gaze" to describe this method, at the same time he alludes to the power of this gaze to conduct surveillance and discipline those at whom it is directed - human bodies and minds, which thus become potential objects of manipulation, not only of the medical profession, but also the state. The methods implemented by its representatives, medical doctors, are only part of the multitude of instruments of state control and repression. One of the consequences of this is that the process of curing, in 
addition to bringing relief to those that suffer, became "an ideological practice that helps in the reproduction of social relations through which the disease becomes real" (Young, 1982, 280). This historical transition from treating diseases based on knowledge and practices of the narrow community, to the professionalized, medical model, is surely related to changes in the wider structure of social relations.

Medical knowledge draws its convincing nature from the power that people ascribe to it, and whose basis is again knowledge as such. It is a matter of a cyclical relation of power and knowledge whose aim is to be eternally reproduced. This does not mean that medical institutions are the only source of disciplinary manipulation - the same is true of the army, educational institutions, and so on, which (like medicine) apply, as Foucault terms it, "the anonymous strategy of domination," which includes "a number of mostly minor processes, with a different origin and location, that overlap, repeat, or imitate each other, find support in each other, and differ according to the area of implementation, they converge with one another and slowly draw a diagram of a general method" (Foucault 1975, 142; translation: author).

The explanation of why a certain model of interpreting changes in the mind and body suddenly started to dominate and be considered "truer" (or, more precisely, the sole truth), repressing previously existing models of interpretation, lies in the power structure characteristic of western societies, whose basis is gender, class, and ethnic affiliation. Official medicine lies mainly in the hands of (white) middle- and upper-class males, in contrast to traditional medicine, which is dominated by village women. An equally important source of power of official medicine is its scientific basis - chronologically, the rise of medicine overlaps with the development of the sciences and the gradual domination of rationality and the scientific world-view, at the expense of the irrational and magic. Scientific rationality goes hand-in-hand with emphasizing the relevance of objective phenomena, numeric measurements, and the notion of diseases as individual entities, as well as reductionism, mechanicism, and dualism. According to this world-view, the body is a machine and illness is interpreted as a defect of one or more of its parts. This metaphorical notion of the body is reflected in the doctor-patient relationship, which now becomes a relationship of 
domination and subordination. The patient is not perceived as a person, as a human being, but is reduced to a "sum of abnormal physiological parameters" (Helman, 2000, 81).

Whereas domination is exercised through specialized, scientific knowledge, subordination presupposes being powerless, passive, and ignorant:

The patient comes to believe in the "truth" of an anatomical map of his/ her body and a medical model of the changes it undergoes as a result of surveillance by the medical practitioner. This gaze is exemplified in the stethoscope applied to the chest of the passive patient, yielding sounds which the patient neither hears nor can interpret. As the object of medical surveillance, the patient comes to "know" their body and their disease through their encounter with the medical practitioner. (Billington, Hockey, and Strawbidge, 1998, 118)

Contemporary medical practices often contain elements that do not have a practical or a technical goal - their symbolic function should induce trust in norms, values, and beliefs regarding the body and healthcare. Such symbolic objects or forms include the white coat of the medical practitioner, his huge desk, framed diplomas, the use of Latin, and so on. The sum of symbols that we face during the ritual time and at the ritual place, during the examination at the doctor's office, which would not have the same effect if faced in another context and individually, should evoke professionalism and authority:

... we believe that the wearer of the white coat encountered in a hospital or surgery has had medical training, is a professional, has the power to examine our body and ask about intimate details of our lives, is reliable, clean and respects confidences and has a high social status ... Moreover, in recognizing the power of medical practitioners and their diagnostic capacities we simultaneously recognize ourselves as altered in terms of our social identity. Personal or private social identities - bank manager, cellist, union leader, market gardener - are set to one side once admis- 
sion to the public space of the hospital marks entry to the more dominant identity of patient. (Billington, Hockey, and Strawbidge, 1998, 119)

As a means of bridging both the symbolic and real barriers that are erected between the highly specialized knowledge of medical practitioners and common people, popular layperson's notions of the human body and the ways it functions are formed. These notions are in fact a filtered, simplified, and often distorted interpretation - in fact, a quasi-medical model of interpretation of the disease - containing scientific elements mixed with elements of traditional knowledge that in most cases are based on magical (non-scientific) notions. In the best-case scenario, this "popular science" approach to medicine is promoted especially by media offering advice on solving certain health-related problems. This knowledge becomes a part of the therapeutic network, and starting from the individual it spreads in concentric circles to the family, neighbors, friends, doctors, and medical institutions. On the one hand, such a therapeutic model illustrates the historical development of healthcare - which, as already seen, started to move from people's homes and communities to public, professionalized spheres. On the other hand, the fact that both spheres still function simultaneously, overlapping and complementing each other, in spite of the theoretical incompatibility of their approaches, is an indicator that people still prefer to have control over their health in their own hands (or to give it away to those closest to them), and that they give up such control in favor of a doctor's help only in cases when the process of detecting the problem (or the problem itself) is too difficult, unclear, and unsolvable for them. Official medicine is thus seldom consulted when it comes to less serious and more common health-related problems that can be solved using empirical knowledge (i.e., lay medical knowledge), but it is also the first choice for symptoms that are more difficult to interpret and diseases that require treatment that cannot be obtained in domestic conditions (e.g., complicated diagnostic procedures or surgery).

In folk culture, less serious health-related problems are also solved in the home, but for more complex injuries and diseases assistance is sought from "specialists." For swollen ankles or broken bones, such specialists are men, especially shepherds, who hone their skills through daily treatment 
of broken animal bones as well as their own injuries. Obrębski calls these injuries "professional diseases" with regard to shepherds and villagers in general $(2001 \mathrm{a}, 116)$. On such occasions, folk medicine offers concrete, efficient solutions. With accumulated experience in mind, changes that occur in and on the body, initiated by an outer agent, are not regarded as a mystery. Thus, for treating mechanical injuries whose cause is known, health magic is not considered relevant or necessary. However, for internal organ dysfunctions, psychiatric disorders, and all types of infectious diseases whose causes lie in the supernatural, one needs a "specialist" whose secret knowledge (or talent) lies in the ability to communicate with those forces and successfully fight them, which is in fact the key to healing.

Communication is established through oral formulae and the use of specific instruments such as deer's antlers, wolf's claws, small knives, horseshoes, spinning wheels, and so on. The existence of such healing methods and belief in their effectiveness can be explained only if one takes into account the wider context of their function, the context of folk culture, in which the notions of man and nature are closely related to beliefs in the supernatural and the power of magic. In folk culture, the corpus of knowledge related to health and disease is an integral part of notions related to life and death. Characteristic magical thinking is so deeply rooted that even today its echo is an obstacle in establishing the biomedical model as the only relevant one.

Between the specialized, scientific knowledge of official medicine and the popular notion of the human body and how it functions, there is a barrier that is sometimes erected with full awareness, to maintain the untouchable nature of the "secret" knowledge of doctors, which is the source of their power. However, such a barrier exists by itself because these two world-views - the scientific and the popular - are of a different nature. What makes the second one popular, quasi-scientific, or completely nonscientific is precisely the fact that it contains elements of the irrational and magic. At first glance, these two approaches exclude one another: the scientific nature of Darwin's theory of evolution, for example, excludes Creationism, and bacteria and viruses exclude the existence of evil spirits and spells. Paradoxically, however, this theoretical incompatibility is not an obstacle to their practical coexistence, which results in the existence of two 
parallel healthcare systems. People turn to them either successively (first to the former and, in case of failure, to the latter), or simultaneously, thinking they can thus maximize their chances of successful recovery.

Despite the attempt to impose the contemporary biomedical model as dominant, especially through education, even today most people's notion of the human body and nature of disease is quite close to that described by Obrębski in the 1930s, when he wrote the following about the inhabitants of Poreče:

The whole corpus of knowledge regarding anatomy and physiology is a strange mixture of exact [i.e., scientific] observation concerning nature on the one hand and, on the other hand, notions about which riddles of life and death are explained in the frameworks of the belief system and views of a religious nature. $(2001 \mathrm{~b}, 116)$

The fact that belief in the effectiveness of magical healing procedures is still vibrant is illustrated by recent field research that treats this topic in both rural and urban contexts (Risteski, 2002; Buldioski, 2003).

So far I have tried to define the main features of folk versus official medicine (i.e., the contemporary model of interpreting and treating diseases), trying to detect points of potential overlap and/or differentiation. Those that perform this interpretation and treat diseases in the first instance are mainly old village women, and in the second instance (especially at the beginnings of official medicine) mainly middle- or upper-class men.

Regarding social space (i.e., where interpretation and treatment are carried out), the place of disease in folk culture was located in the home and its immediate surroundings, in the intimate and private sphere of the ill person.

On the other hand, official medicine is a publicly institutionalized space, symbolically and physically separated from the home of the patient by hospital walls. The "governors" of this space are "scientists" - medical doctors whose almost esoteric, elitist, and specialized knowledge accords them high professional and social status and/or power. The power-knowledge relation- 
ship exists even when it comes to folk healers - those that are skilled in using healing plants, making balms, and healing swollen parts of the body possess specific knowledge and skills that are highly appreciated. Special respect is paid to those that possess knowledge of magical healing procedures, and who have a talent for communication with the "other side." However, the power of such healers, in contrast to that of doctors, is not fed by the symbolic barriers between them and others in the sense of their professionalism, formal education, and physical isolation in separate public institutions. Those that seek assistance do not change their identity during the healing procedure - these persons are not even labeled with a special term to illustrate their role, as in official medicine, in which the person suffering from a certain disease is labeled a patient - a term associated with being submissive and passive. Official medicine, regardless of whether it comes from the public or private sector, charges for its services, and patients' financial ability is often directly connected with the chance of receiving the necessary treatment and care, and even with the chance of survival!

Although they do not directly require it, folk healers receive a certain reward so that the cure is effective, but there is no fixed pricelist - everyone gives as much as they can and find appropriate. Some even avoid direct, physical contact with money and do not want to take it from the hands of the client. From my own experience, a healer (a folk chiropractic) from a Skopje settlement asked me to put the money after treatment on the bed; her father, from whom she inherited the skill, made her swear not to practice for financial gain, for otherwise she would lose the talent. In addition, folk healers perform individually, but their number (especially today) is relatively small, so that competition regarding the territory and problems that they cover is almost impossible.

At the same time, in the framework of the medical profession, in addition to obvious competition there is still the principle of a kind of guild solidarity. Such an attitude was formed at the very beginning, when medicine was established as science and practice, but even today this is a foundation upon which it functions globally. This is also one of the few elements that, contrary to a number of others that went through a certain transformation, survived in identical form through the centuries of transmitting and 
modifying the Hippocratic Oath, which has different versions in different medical, religious, and social settings.

\section{Stigmatization, Isolation, and Fear}

The negative discrimination and stigmatization of the ill, especially those suffering from infectious diseases, can be followed through the entire history of mankind. What is considered a serious disease by folk and official medicine is almost the same - a disease that is long-lasting and has a fatal outcome. There are a number of identifying signs of the seriously ill in folk culture: bodily changes (the eyes "drop" and change color, the mouth dries out and cracks, weight loss, etc.), lack of appetite, high fever, and unconsciousness: "If his tongue fattens he will not rise in due time," "If his eyes are covered with a white curtain, he will die" (Cepenkov, 1980). Such symptoms create fear for the life of the ill person.

However, when a serious disease is also contagious, the problem and the fear become collective. Those that are ill now also become dangerous, and contact with them is not desirable. Isolated and stigmatized, they die in a social sense, before the disease marks their physical end.

As already mentioned, it is precisely contagious diseases, their causes, and the methods for curing them that are the biggest riddle of folk medicine and the folk world-view in general. In this area, as well as in other areas of life, knowledge related to everyday life experience and the awareness of natural processes are interrelated with beliefs concerning the supernatural - both models of interpreting different events in people's lives, including the causes of falling ill, create a coherent whole, in which duality (and thus the effect of contradiction) between the rational and irrational in fact does not exist.

Thus, potential causes of accidents (in this case, diseases) could with an equal degree of probability belong to one of the following spheres: individuals themselves (e.g., health disorders resulting from changes in food consumption or behavior), nature (e.g., injuries caused by animals or disorders due to climate changes and influences), the social environment (e.g., evil spells and black magic), and the supernatural (e.g., evil spirits and God). 
Graphically, the location of responsibility with regard to diseases is represented in Figure 1:

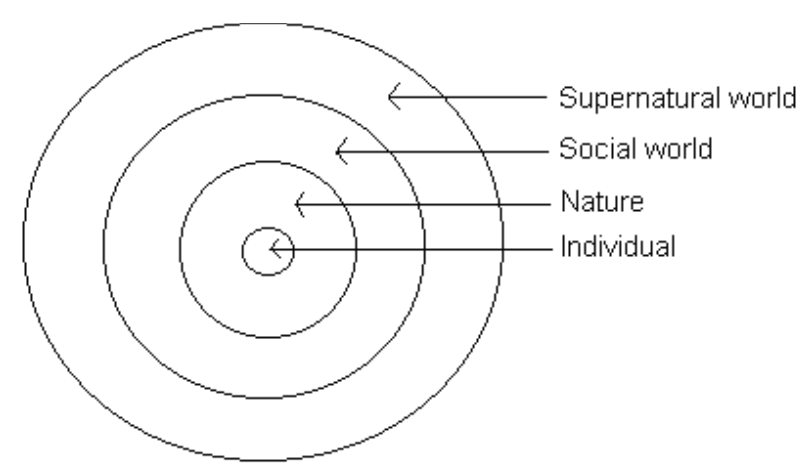

Figure 1: The potential location of disease sources source: Helman $(2000,91)$

Analysis of available materials shows that in Macedonian folk culture the responsibility for disease depends on the type of disease itself - for example, if it is a broken bone, then the responsibility lies in the sphere of nature; if it is impotency, then the problem lies in the social environment, and so on. However, the individual as a potential location - that is, as the source of disease and his or her responsibility - seems to be absent. Certain studies have examined people's opinions about who is responsible for their impaired health - whether it is a result of their own behavior, food consumption, or perhaps emotions. These studies indicate that the basic and decisive element upon which people base their opinions is their economic control over their own lives: those with better economic control over their lives assumed more responsibility for their own health (Pill and Stott, 1982). Those that thought of themselves as socially and economically disadvantaged believed that disease was the result of external forces over which they had no control, and that they therefore did not bear any personal responsibility. Such results would be acceptable when it comes to contemporary culture - however, in folk culture not only economic but also more general control over one's life (which is considered managed by forces outside one's own body, forces that do not take the individual's will 
into account) can be a reason for locating the source of diseases further from (or more precisely, outside) the individual's body.

Such is the case in interpreting the etiology of diseases affecting both individuals and the community. Epidemics that have devastated entire villages and regions in Macedonia were not rare. In eastern Macedonia, when a certain disease would spread through a whole settlement or through the whole village, people said that there was poreduška or porazija 'catastrophe'. The same phenomenon was called purdija in the Gevgelija and Dojran areas. However, quite often a synonym for serious epidemics is 'the plague'. This term has a multitude of meanings that are often not easy to detect in a given context - sometimes it is a matter of a serious contagious disease that informants have heard of being like something that existed in the past, other times it is a common name for a number of different serious diseases, and most often it is a personification of an abstract but destructive force - an evil that strikes the community and can be overcome only if the community strikes back with mutual efforts. In addition, 'the plague' also refers to any kind of misfortune that can harm individuals, through magic, if they are cursed with a formula that contains this term. Such curses include: Čumata da go stigni na mestoto da go ostave 'May the plague catch him and kill him on the spot', Čumata da go zatrie 'May the plague devastate him', Čumo, deka odiš, deka šetaš, ta da ne dojdeš da go grabneš 'Oh plague, where do you go, where do you stroll, why don't you come get him', and so on (Kitevski, 1997, 63).

The plague as a metaphor for a dangerous enemy is a frequent motif in heroic poems, in which individual heroism is proved through fighting this evil force that threatens the community. This is probably why these poems also call the plague a "heroic disease." Such a metaphorical use of the term 'plague' is well known in the European context, in which it is associated with social chaos and dissolution of religious and moral fabric. Jean Delumeau, a researcher of medieval European history, in his renowned book Le Peur en Occident (Fear in the West), asserts that the plague was one of the greatest fears of mankind during the Middle Ages in Europe. Analyzing the typology of collective behavior at the time of the plague, he follows the dissolution of the social tissue that falls under the much stronger instinct for survival: "Relations between people are totally misbalanced: at the very 
moment when the need for others is indispensable and when they would usually assist you, now they let you down. The time of the plague is a time of enforced loneliness" (Delumeau, 1978, 156; translation: author). The body of the community and the body of the medieval city vanish the same way as the body of the one that caught the disease - his death is depersonalized and desacralized. Such a destruction of the social order created an atmosphere of despair and madness - according to Delumeau, this is mostly a result of the absence of collective ritual activities, especially those related to death, which up to that very moment had brought the community stability, dignity, and identity: "In the period of the plague, as well as during wars, the human end occurred in circumstances of unbearable disorder, outside customs that were deeply rooted in the collective unconsciousness" (Delumeau, 1978, 157; translation: author). In addition to the plague, such a metaphorical meaning in the twentieth century was ascribed to other diseases such as tuberculosis, syphilis, and especially cancer, which in the media, literature, and popular discourse of the twentieth century was described as an entropic evil force, specific to the modern world, which consists of primitive, atavistic, and chaotic cells that go out of control and thus destroy the natural order of the body (and society). Criminality, terrorism, drug use, strikes, and immigration are all described as cancers of contemporary society - a demonic force that slowly crushes the established order (for more on illness as a metaphor, see Sontag, 1978).

Following the trail of the plague as a separate disease, but also as a mythological trope in Macedonian folklore, I started with an analysis of the possible presence in Macedonia of the disease with which it is primarily associated - the Black Death or the Black Plague, one of the most devastating pandemics in human history, responsible for the deaths of over 75 million people. In its first appearance alone (1346-1350), it killed around one-third of the European population (Tuchman, 1984, 137). Although the plague disappeared from Europe in its virulent form in the eighteenth century, there are still memories of its presence preserved in many European languages - for example, the term 'plague' in Macedonian above; in some other languages it is also often used in a metaphorical sense to describe a phenomenon that spreads rapidly, causing great danger. 
In Macedonia, the Black Death was registered during the Turkish-Austrian war (at the end of the seventeenth century), when the Austrian general Piccolomini, aiming to stop the spread of the epidemic, burned the city of Skopje:

According to various archived writings, Skopje suffered the most during the Austrian rule of the city (1689). This fire destroyed the beautiful and developed city of Skopje and much time passed before it could be resurrected. Even worse, at the same time the plague devastated its inhabitants. According to these writings, only a handful survived the disaster. (Todorović, 1927, 61)

The memory of Skopje being affected by the plague is preserved in a number of folk songs. For example, in the song "Mitre and the Plague," Mitre returns home after working in Istanbul for three years, staying overnight in a hostel in Skopje. In the morning he meets an old woman:

And said Mitre, the hero:

"Oh grandmother, old grandmother!

What a strange scene,

I stayed in Skopje overnight,

I kept hearing the roosters crow,

The roosters crowed, the dogs barked,

But I did not see a single living soul."

Then the old woman said:

"Oh Mitre, my dear son!

I am not an old woman, son,

I am the Black Plague!

Everyone, son, has escaped."

Then Mitre said, "Please grandmother

Look inside this book of yours,

See if I am in it!'The old woman looked in the book, 
She looked at him and said:

"You, son, you are also in it!"

(Miladinovci, 1983, song no. 195,

"Mitre and the Plague"; translation: author)

This notion of the plague as an old woman that carries a list of names of people that will die is one of the personifications of this disease. It is represented as a woman that has the power to turn into an animal (a bird, cat, or dog), who has long, tangled hair, a terrifying face, long hands, and a basket containing a needle, a knife, a stone, a razor, an axe, or a scythe, which she uses to commit her murders (Vražinovski, 1998, 201).

Filipović, in his study of the Skopje Basin, says that both the Muslim and Orthodox population in this area imagine the plague as an old disheveled woman that wants to enter houses and comb her hair. According to his informants, she "beats people under the arms, creating a swelling that bursts after some time" (Filipović, 1939, 245). This resembles the symptoms of the bubonic type of plague that manifests itself through swelling of the lymph glands under the arms, on the throat, and in the groin.

Attempts to explain causes of evil are attempts to rationalize it, and should lead towards an effective solution and final victory over it. According to one such "explicative schema" (as Delumeau calls them), constructed to explain the emergence and spread of the plague in the Middle Ages, death was caused by contaminated air and water - but contaminated by Jews, beggars, and lepers. The plague was an excellent way to direct collective aggression towards those that were already treated with distrust, those that were on the margins of the community. The stigmatization of the Other as a source of disease, evil, and ugliness is reflected in Macedonian folklore as well, and it is in this sense that one can interpret the representations of the plague not only as a woman, but also as a Gypsy or Vlach woman. The "unclean" disease (and disease is such by default) is related to "unclean" Others. In the contemporary context, for example, such is the association of HIV-AIDS (the "plague" of the twentieth century) with homosexuals. 
The perception of this disease as exclusive to the gay population is exactly the result of association of unclean sexuality with unclean disease.

Among the legends about the origin of the plague, one is especially morbid and unclean. The story "How the Plague was Born" in the collection by Cepenkov $(1980,125)$ tells how in a kingdom over nine seas there lived an emperor who was the most evil in the whole world. His greatest pleasure was to dishonor every woman he saw. However, one girl, a poor one, dedicated to God, put up great resistance, so the emperor, after torturing her for some time, finally killed her. The girl died, but the damned emperor raped the dead body and then threw it in a cellar. After nine months of waging war outside his kingdom, he returned and found the girl's body in one piece, but her heart was swollen and inside it something moved as though it were alive. The emperor kicked the heart and the plague came out of it. This origin of one of mankind's most serious diseases is thus associated with a combination of two major human sins - rape and necrophilia. The misogyny represented when speaking about the plague personified as woman is softened here. The disease is really "born" from a girl's dead body (out of her pure heart), but the vengeful mission is justified by its traumatic conception from a sinful father: here the sinful deeds of the man, and not a woman, are the true reason for the devastating nature of this disease which, according to this legend, started to spread after it killed the evilest one of all: its own father.

This article has mostly referred to epidemic diseases because they represent an excellent illustration of a collective response to a collective threat. Contrary to the semi-intimate character of other types of diseases or disorders that could remain isolated (both as news and treatment) within the home of the ill person and his or her family, remaining relatively invisible, a contagious disease is paradigmatic regarding the treatment of disease in a social context. Metaphorically speaking, if a less serious, non-contagious disease whispers, then a serious contagious disease screams - and its terrible voice echoes in every corner of shared space, which becomes an arena of a common fight for survival and salvation. Life reduced to its marrow - this is how the atmosphere of the village or the city struck by epidemics could be described. The chaos characteristic of a ritual time, in which social bonds are deliberately revoked (but only temporarily, until order is established 
again) in the case of epidemics is imposed unexpectedly and unwillingly. According to Delumeau, what is called into question, in addition to biological survival, is the concept of the future, without which life simply becomes worthless: in normal times even an old man acts in accordance with the future, and he not only builds but also plants fruit trees. It is inhuman to live without an idea of the future. Epidemics force man to perceive each moment as a temporary postponement of punishment, while at the horizon there is nothing other than death approaching (Delumeau,1987, 159).

Although it seems like a paradox, epidemics, in addition to being responsible for such an essential breakdown of social order, are at the same time the reason for its consolidation and even stronger establishment. The medical institutions and obligatory vaccination systems (which often, as in the case of Macedonia, are part of state responsibilities) that also include announcing epidemics and reacting to them are a result of the very processes that were already mentioned by Foucault, of the strategies that are raised every time there is a need for response to a certain unexpected and thus often dangerous phenomenon that needs to be brought under control. "Microorganisms enter in interaction not only with our organic bodies, but also with our institutions," says De Landa, "putting selective pressure upon them and thus acting as an instrument for establishing their routines" $(1997,12)$. From the ashes of destructive disease (influencing the body of the individual as well as the "body" of the community) rises a new, empowered, and enriched social structure.

According to supporters of the "theory of constructed fear," which is in fact a variation of conspiracy theory (e.g., movie director Michael Moore in Fahrenheit 9/11 or Illo, or linguist Noam Chomsky - see especially Chomsky, 1999), such a mechanism of control over a potentially dangerous situation is often misused by ruling structures to reproduce their power. The main motive for an intentional policy of spreading fear is increasing social control, so that in such situations the frightened population, persuaded that it has no other choice, places its trust in "responsible" institutions (politicians, doctors, the army, and the police). Thus, creation of health-related fear (e.g., the fear of secondary nicotine poisoning, vaccines that could lead to autism, toxic water, or real or fictitious epidemics) is one of the most effective bases for activating such a mechanism, involving the spreading if 
disinformation or semi-truths, and manipulating statistics, words, sources, or data - and all of these for someone's economic and/or political interest.

It has been shown how diseases can first demolish and then regenerate the collective psyche. However, in addition to being a result, an "ill psyche" can also become a reason for individual diseases. Psycho-somatic or psycho-physiological disorders are diseases that are induced by mental rather than physiological causes. The body reacts to stressful emotional conditions such as fear, depression, guilt, and anxiety, and this can cause a wide spectrum of physical symptoms, such as headaches, vertigo, hair loss, stomach pain, skin reactions, and so on. Such an attitude according to which psychological conditions (or the conditions of the spirit) can cause material manifestations - that is, bodily changes - is relatively new in official medicine. However, in addition to its promotion at a formal level, in practice the treatment of disease is again partial and directed towards physical symptoms, without taking into account individuals' personalities or their current psychological situation, which in certain situations is a key factor for interpreting causes of diseases and thus their cure.

This is a result of the gap between the biological and psychoanalytical interpretation of the body - the former promotes a biological approach and deduced psychological life from neurology, whereas the latter asserts that the laws of biology are total fiction (Miller, 2001). However, there is no such dilemma in folk culture and medicine. The stressful psychological condition, in Macedonian most often called strav 'fear' or uplaf 'anxiety', is considered a cause of a number of diseases that are manifested through various physical symptoms. Thus, in Obrębski's materials, fear or anxiety are a cause for nine potential forms of the disease called dalak 'splenitis', which can be "thrown" - that is, physically manifested in the mouth, the eye, the nose, under the tongue, or in the nose: "dalak, this comes from fear" (Obrębski, 2001b, 122).

The same is true of fever, which can be caused by spoiled food and water, unripe fruits, and also by fear: "It will shake him, from fear, from food. Someone will have too much food, or someone will be scared, and thus come down with a fever" (Obrębski, 2001b, 125). The informant is even more precise when it comes to the disease called palajca. It is manifested through small 
measles that can spread over the entire body, create a rash, and appear due to gajle 'worry': "If you weep for your mother, your sister, if you are sad about something. If you crave something, if someone is chasing you, if he yells at you" (Obrębski, 2001b, 124). Fear is said to be the reason for a few other diseases: jeftika, a type of respiratory disease ("No one knows where it comes from. Some say from fear: when you get scared;" Obrębski, 2001b, 126); majasil 'piles' ("If you are worried, or if you are scared you'll catch majasil;" Obrębski, 2001b, 127) and sekajca, manifested through severe headaches ("If you get scared, your head will start hurting;" Obrębski, 2001b, 127).

These are totally different diseases that can be caused (to use the language of contemporary psychology and medicine) by stress! In medical literature, stress is defined as a physical or psychological reaction to a strong external stimulus that could lead to disease, or distortion of the organism's homeostasis caused by stressful experiences, regardless of whether these are real or imaginary (The World Book Medical Encyclopedia, 1991, s.v. stress). This definition seems quite close, if not identical, to those inner experiences described by Obrębski's informants when they speak about their uplaf. Although the sources of stress in a village community and in an urban setting could be different, the response of the organism to it in both cases (acknowledging individual differences in stress management) is quite similar. The difference, which is more a question of form, lies in the methods for dealing with it: official medicine prescribes medications, popular psychology prescribes various self-help techniques, and the folk healer prescribes magic.

\section{Disease as Social Disequilibrium}

At the beginning of this article, disease was defined as a distortion of an organism's homeostasis (or equilibrium) that could cause its general dysfunction. In fact, there are two types of dysfunction that disease causes, which are interrelated: distortion of the normal function of the body and its organs and, as a result of this, distortion of the individual's functioning in a social sense. Ill persons can become partly or completely unable to participate in social life, but can also be forcefully excluded, as a result of physical 
isolation (quarantine), but also stigmatization and social quarantine that happens regardless of the actual health condition and the person's feeling in relation to his or her own health. "Participation in social life" means that individuals are capable of and fulfill common social roles and responsibilities that they had up to the moment of becoming ill; in this sense, disease can be considered a distortion of both bodily and social homeostasis.

The more serious a disease is, and the longer it lasts, the more severe the imbalance seems; in the case of a less serious disease, balance is reestablished sooner, both bodily and socially. Disease damages individuals' working ability, which is highly valued in both folk and contemporary culture. However, contrary to contemporary urban settings, in which technology can compensate for some loss of working ability, in rural agrarian or stockbreeding economies, especially in the past, health and physical strength are directly related to working ability. In the hierarchy of folk values, health ranks higher than working ability, but also higher than any type of material possession: health is simply the highest life priority. Work and life quality depend on it: a person that is ill cannot work and cannot get rich; he lives "without God's blessing;" in a word, an ill person is miserable.

Fear of disease is identical to fear of death. For humans, who are aware of their mortal nature, this has been and will remain the greatest primal fear - the basis of almost all others. In this sense, people today do not differ from those in the past; the development of science and technology provide a deep and detailed view of bodily processes and help rationalize the phenomenon of disease, but this does not seem to influence our irrational fear of it. Disease is a threat to the health and life of healthy persons, as well as the social life of those that are ill: to be ill, especially with a serious contagious disease today, in all contemporary societies, means to be marginalized and discriminated against to a greater or lesser degree.

There is even a special term that describes this practice of discrimination against the ill by the temporarily healthy: "disease." Efforts to change attitudes towards the ill as being unclean, dangerous, and socially useless find a basis in language - in English, for example, a number of euphemisms are used to describe diseases, such as "condition," and persons ill with HIVAIDS are politically correctly referred to as PLWA 'Persons Living With 
AIDS'), a term that is preferred because "it emphasizes the positive concept according to which AIDS is something that one can live with" (Beard and Cerf, 1993, s.v. PLWA).

Such intellectual constructions do not soften or change reality; they only illustrate the discomfort of contemporary western culture in which disease is a taboo, the same way death is a taboo. Contrary to contemporary culture, folk culture - in addition to the universal, deeply rooted human fear of the unknown and the dangerous - categorizes disease in phenomena that are an integral, "natural" part of human life, which consists of phenomena that can, hardly can, or cannot be explained. Health is something to be safeguarded, and thus it is wished to others as the most precious gift. Blessings and toasts as sacral texts present a wish for fertility, and for a good life in general - but as a condition for them both, above all, "good health!"

\section{REFERENCES}

Beard, H., and Cerf, C., The Official Politically Correct Dictionary and Handbook, New York, 1993.

Billington, R., Hockey, J. and Strawbidge, S., Exploring Self and Society. Basingstoke, 1998.

Buldioski, D., Narodna medicina kaj mladi vo urbani sredini. Undergraduate thesis, Skopje, 2003.

Cepenkov, M., Makedonski narodni umotvorbi Vol. 8 and 9, Skopje, 1980.

Chomsky, N., Necessary Illusions: Thought Control in Democratic Societies, Boston, 1999.

De Landa, M., A Thousand Years of Nonlinear History, New York, 1997.

Delumeau, J., Le Peur en Occident (XIVe-XVIIIe siècles), Paris, 1978.

Filipović, M., Običaji i verovanja u Skopskoj kotlini, Srpski etnografski zbornik 54, 1939, 280-566.

Foucault, M., Surveiller et punir, Paris, 1975. 
Foucault, M., The Birth of the Clinic: An Archeology of Medical Perception, 2003.

Geertz, C., Local Knowledge: Further Essays in Interpretive Anthropology, New York, 2000.

Helman, C.G., Culture, Health and Illness. 4th ed., Oxford, 2000.

Kitevski, M., Makedonski narodni kletvi, Skopje, 1997.

Kleinman, A., Patients and Healers in the Context of Culture, Berkeley, 1981.

Miladinovci, D. and Miladinovci, K., Zbornik na narodni pesni, Skopje, 1983.

Miller, J.-A., Lacanian Biology. Lacanian Ink 18, 2001.

Obrębski, J., Makedonski etnosociološki studii, Skopje, 2001.

Obrębski, J., Folklorni i etnografski materijali od Poreče, Skopje, 2001.

Pill, R. and Stott, N.C.H., Concepts of Illness Causation and Responsibility. Some Preliminary Data from a Sample of Working Class Mothers, Social Science and Medicine 16, 1982, 43-52.

Risteski, L.S., Narodnite iscelitelki vo Poreče od vremeto na Jozef Obrembski do denes, In: Tanas Vražinovski (ed.), Zbornik: 70 godini od istražuvanjata na Jozef Obrembski vo Makedonija, Prilep, 2002.

Sontag, S., Illness as Metaphor, New York, 1978.

Todorović, Č.J., Skoplje i njegova okolina, Južni pregled - posvečeno Kongresu jugoslovenskih učitelja, 1927, 61-71.

Tuchman, B.W., Daleko zrcalo. Zlosretno XIV stoljeće, Zagreb, 1984.

Vražinovski, T., Narodna mitologija na Makedoncite, Institut za staroslovenska kultura Prilep, Skopje, 1998.

World Book Medical Encyclopedia, Chicago, 1991.

Young, A., The Anthropologies of Illness and Sickness, Annual Review of Anthropology 11, 1982, 257-285. 


\section{»ŽIVLJENJE BREZ ZDRAVJA - ŽIVLJENJE BREZ VREDNOSTI«: PRIMERJAVA LJUDSKE IN BIOMEDICINSKE RAZLAGE BOLEZNI V MAKEDONIJI}

Ključne besede: telo, zdravje, bolezen, ljudska kultura, Makedonija, epidemija, evropska zgodovina, biomedicina, psihosomatska bolezen

\section{Povzetek}

$\mathrm{V}$ članku poskušamo orisati idejni okvir razlage telesnih sprememb, povezanih z zdravjem, na podlagi etnografskih primerov iz makedonske ljudske kulture in ga primerjati z biomedicinskim »uradnim « znanjem v zvezi $s$ tem pojavom. Pri tem želimo ugotoviti, ali se ljudsko in uradno znanje prekrivata. Poudarek je na družbenem položaju človeka, ki trpi za določeno boleznijo, še posebno za vrsto nalezljive bolezni, kot je bila v srednjem veku kuga in kot je $\mathrm{v}$ današnjem času aids. 